\title{
吸引鐘を用いたコンクリートの簡易透気試験法に関する基礎的検討と スケーリング抵抗性評価への適用の試み \\ EXAMINATION OF RAPID AIR PERMEABILITY TEST WHICH USED VACUUM CHAMBER AND APPLICABILITY TO SCALING EVALUATION FOR CONCRETE
}

\author{
権代由範*, 月永洋一**, 阿波稔***, 迫井裕樹**** \\ Yoshinori GONDAI, Yoichi TSUKINAGA, Minoru ABA \\ and Yuki SAKOI
}

\begin{abstract}
Rapid air permeability test using vacuum chamber was examined in testing conditions and the validity as the evaluation method of scaling resistance. The testing condition of rapid air permeability test was decided based on the outcome of an experiment. For the rapid air permeability test, the sealing width of $60 \mathrm{~mm}$ was secured around the chamber and a distance of $150 \mathrm{~mm}$ was secured from the specimen edge to the center of the chamber. These test conditions reduced the coefficient of variation to $15 \%$ in the air permeability test. Rapid air permeability factor was found to be in good compatibility with Torrent air permeability factor. Also, this factor was found to be compatible with the amount of scaling by the ASTM C672 method. As a result, the usefulness of the rapid air permeability test method was proven.
\end{abstract}

Keywords : Concrete, Surface layer, Rapid air permeability test, Vacuum chamber, In-situ test, Scaling resistance コンクリート，表層部，簡易透気試験，吸引鐘，現位置試験，スケーリング抵抗性

\section{1. はじめに}

コンクリート表層部は, 水, $\mathrm{CO}^{2}$, 塩化物イオン等の劣化外力に 対して鉄筋を保護するという機能を有し，その品質の良否は構造物 の耐久性を大きく左右する。実構造物コンクリートを対象とした場 合, これら劣化外力の侵入・拡散の程度は, コンクリート組織の緻密 性を間接的に表す透過性 ${ }^{1)}$ から評価することが可能であり，コンク リート表層部の透過性を現位置で簡便に測定できる簡易試験法は, 構造物の耐久性照査や維持管理において有用な情報の提供を可能と する。一方, コンクリートの凍害における劣化外力は, 水の侵入と 凍結融解の繰返しが支配的であり，この劣化外力を作用させる試験 として凍結融解試験 (JIS A 1148) が広く用いられている。この試験法 は, 供試体の相対動弾性係数と質量減少率を評価指標としているが, これらの指標はコンクリート自体の耐凍害性を相対的に比較するも のであり，実構造物コンクリートの耐凍害性を直接的に評価したり 予測したりするものではない。このことから, 実構造物コンクリー 卜に適用可能な耐凍害性試験や評価指標の提案が求められている。 ここで劣化外力としての水に着目寸ると, 凍害は本質的に水の侵入 がなければ生じないことから, コンクリートへの水の侵入の程度を 指標とすることにより，耐凍害性を評価できるものと考えられる。

著者らは以上の観点から, コンクリート表層部の透過性に着目し， この透過性を指標とした耐凍害性評価手法, 特に, スケーリング抵
抗性評価手法の確立を目的に，実構造物コンクリートに適用可能な Figg 法 ${ }^{2)}$ 応用した簡易透気試験や簡易吸水試験 ${ }^{3), 4}$, 独自開発した 簡易透水試験 ${ }^{5)-8)}$ について検討してきた。しかし，これらの方法は コンクリート表層に直径 $10 \mathrm{~mm}$ ・深さ $30 \mathrm{~mm}$ の削孔を設ける方法で あり，試験の簡易性という点で課題を残していた。このことから， 本研究では, 純非破壊試験として実構造物に適用可能な, 吸引鐘を 設ける簡易型の透気試験法について検討を行っている ${ }^{99}$

\section{2. 本研究の範囲と位置付け}

実構造物を対象とした透気性試験に関する研究は古くから行われ ており，これらの成果は氏家によって 1994 年当時に紹介され ${ }^{10)}$, 近年の現状については今本らにより報告されている ${ }^{11)}$ 。多くの提案 がなされている透気試験法であるが，試験方法の特性から，Figg 法 に代表される削孔法とコンクリート表面に装置を設置する表面法に 大別され，さらに表面法についてはシングルチャンバー法とダブル チャンバー法に分類される。本研究では純非破壊という観点から表 面法に着目し，特に，吸引鐘を用いたシングルチャンバー法に関す

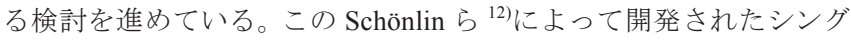
ルチャンバー法は, 試験時間や測定作業の簡易性に優れる反面, ブ リーディングや表面仕上げ，早期脱型等によって形成される表層脆 弱層が試験結果に大きな誤差をもたらす可能性のあることが報告さ
* 仙台高等専門学校建築デザイン学科 助教・博士 (工学)

** 八戸工業大学工学部土木建築工学科 教授 ·博士 (工学)

*** 八戸工業大学工学部土木建築工学科 准教授・博士 (工学)

**** 八戸工業大学工学部土木建築工学科 講師・博士 (工学
Assistant Prof., Department of Architectural Design, National College of Technology, Dr. Eng.

Prof., Department of Civil Engineering and Architecture, Hachinohe Institute of Technology, Dr. Eng.

Assoc. Prof., Dept. of Civil Engineering and Architecture, Hachinohe Institute of Technology, Dr. Eng.

Assistant Prof., Dept. of Civil Engineering and Architecture, Hachinohe Institute of Technology, Dr. Eng. 
れている ${ }^{13)}$ 。国内においても, Schönlin ${ }^{12)}$ の方法と同様の方法が, 福島ら ${ }^{14)}$ や今本ら ${ }^{15}$ によより提案されている。吸引鐘を用いた透気試 験に関しては, 近年, 今本らが気密性や含水率の影響評価といった 観点から, 試験室および実大壁レベルにおける試験法の適用性につ

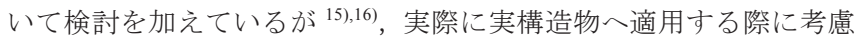
しなければならない測定対象部材の寸法や測定位置などの適用条件 に関する情報はまだ少ないように思われる。さらに, 透気試験全般 が抱える問題である含水率の影響を排除するためには，対象となる 測定位置の含水率を任意に調整することは容易でないため, 含水率 の影響を予め定量的に把握した上で評価に反映させるか，或いは， 適切な測定を可能と寸る適用条件 (適用部材の寸法や測定位置の違 いによる影響等)を明確に示寸必要があるものと思われる。

一方，本研究において透気性からその抵抗性を評価しようとする スケーリングは，凍害による劣化形態の一種であり水分や塩化物の 侵入・拡散により著しく促進されることが知られている ${ }^{17)}$ 。このス ケーリングの抑制策については多くの研究がなされているが，透水 型枠工法の適用 ${ }^{18)}$ や浸透性吸水防止剂の塗布 ${ }^{19}$ に代表される表層組 織の緻密化が有効であるとの報告がある。このことから，純非破壊 試験の透気性試験によりコンクリートの緻密性を評価し, 実構造物 のスケーリング抵抗性の評価が可能となれば，耐久性照查や維持管 理の観点から，有用な情報を提供することが可能となる。

本研究で提案する透気試験法は, 原理的には Schönlin ら ${ }^{12)}$, 福島 $ら^{14)}$, 今本ら ${ }^{15)}$ の試験法と同様の方法であるが, 計測圧力範囲を限 定せず，吸引鐘内が真空状態から大気圧に戻るまでの経時的な圧力 変化を包括的に把握し, 独自に設定した透気性指標值の算出方法を 適用することで，より試験精度を向上させた試験法とすることを目 的としている。ここで提案する方法を適用した場合，計測に時間を 要するという課題が残されるが, 本研究では, 試験装置の作製や計 測作業の容易さから本試験法を「簡易透気試験法」と定義する。

以上より本研究では, 実験シリーズI として, 本研究で提案する 透気性指標值の算定方法の妥当性を評価するとともに, 実構造物 の適用条件を明らかにするため, 吸引鐘外周の試験面シール幅, 吸 引鐘設置位置と部材端部までの距離, コンクリート部材の厚さ, 吸 引鐘のサイズの違いが透気性試験の計測結果に及ぼす影響ついて, 基礎的な検討を行った。また, 適用実績に優れるトレント透気試験 法 ${ }^{20)}$ との相関性を評価することで簡易透気試験法の有用性について 検討した。さらに，実験シリーズII として，簡易透気試験法のスケ ーリング抵抗性評価手法としての適用の可能性を探るため, 簡易透 気試験により得られる透気性指標值と ASTM C672 法 ${ }^{211}$ により得ら れるスケーリング量との相関性について, 比較・検討を行った。

\section{3. 本研究で実施した各透気試験方法の概要}

\section{1 簡易透気試験法 $^{9}$}

写真 1 に, 本研究で作製した簡易透気試験装置と試験状況を示す。 また, 図 1 には透気試験装置各部の接続図を示す。本装置は, 一般 に市販される吸引鐘 (材厚 : $5 \mathrm{~mm}$, 内径 : 100mm, 内容積 : $1015 \mathrm{cc}$, 材質: 硬質ガラス), 差圧計, デジタル・マルチメーター, 真空ポンプ (排気速度 : $5 \mathrm{~L} / \mathrm{min}$ ), 耐圧ホース, パーソナルコンピューターによ り構成される。本装置は、コストパフォーマンスに優れ, トレント 透気試験装置 (購入費)の $1 / 10$ 以下での製作が可能である。

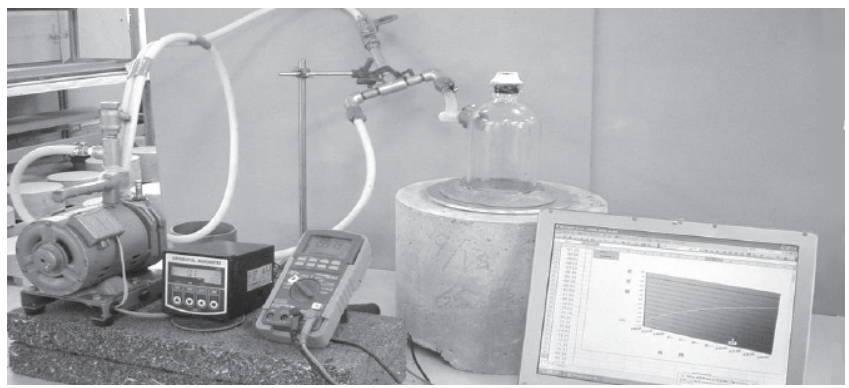

写真 1 吸引鐘を用いた簡易透気試験装置と試験実施状況

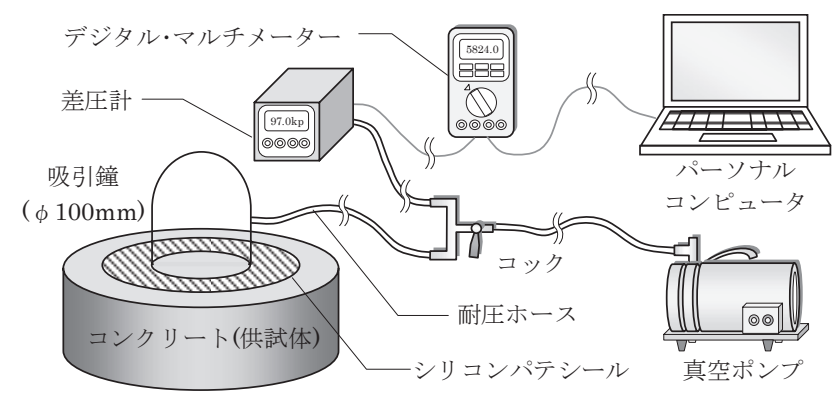

図 1 簡易透気試験装置の接続図

コンクリートへの吸引鐘の設置材料は，気密性を十分に確保でき ること, 着脱が容易で設置材料を取り除く際にも表面に損傷を与え ないことの 2 点を満たすものとして, 非硬化型のシリコンパテを選 定した。このシリコンパテは，空調配管の間隙シール材として用い られるものであり, 事前に行った予備実験から, エポキシ樹脂によ るシールと同等の気密性を確保できることを確認している。

本装置を用いた簡易透気試験の測定手順を以下に示す。

1）測定対象面をアセトン, エアコンプレッサーにより清浄な面とし， シリコンパテを用いて，空気漏れが生じないよう十分に配慮し ながら，吸引鐘を測定対象面へ設置する。

2）吸引鐘に接続した真空ポンプにより，吸引鐘内の圧力を大気圧 との差が-97kPa となるまで減圧し, 真空ポンプを停止させる。 ここで, 減圧に要する時間の違いが計測結果に及ぼす影響が懸 念されるが，本実験での減圧時間は 25〜30 秒の範囲に分布し ており，調合等に起因する時間的な傾向は認められなかった。

3） $-97 \mathrm{kPa}$ まで減圧した吸引鐘内の圧力が大気圧(測定開始時の圧 力)に戻るまでの圧力変化時間と圧力変化量を, パーソナルコ ンピューターの自動計測プログラムにより計測する。なお，圧 力変化量は， $-97 \mathrm{kPa}$ を基点 $(0.00 \mathrm{kPa})$ として記録する。

上記の測定により得られた吸引鐘内の圧力変化時間と変化量との 関係から，簡易透気試験における透気性指標值を算出する。本試験 法は，計測圧力範囲の拡大により計測に時間を要することとなった が，圧力変化時間および圧力変化量の自動計測化によって作業性は 確保されており，また，後に述べるが，試験值の変動係数を小さく することが可能であることを明らかにしている。

図 2 に, 簡易透気試験における圧力変化時間と圧力変化量の計測 結果の一例を示寸。図 2 から, 単位時間当たりの圧力変化量を求め ることにより透気性指標值を得ることが可能であると考えられるが, 両者は曲線関係にある。そこで，圧力変化時間を平方根として処理 した場合の両者の関係を図 3 に示す。圧力変化時間を平方根とする ことで, 圧力変化量 $25 \sim 60 \mathrm{kPa}$ の範囲 (大気圧との差-72〜-37kPa に 


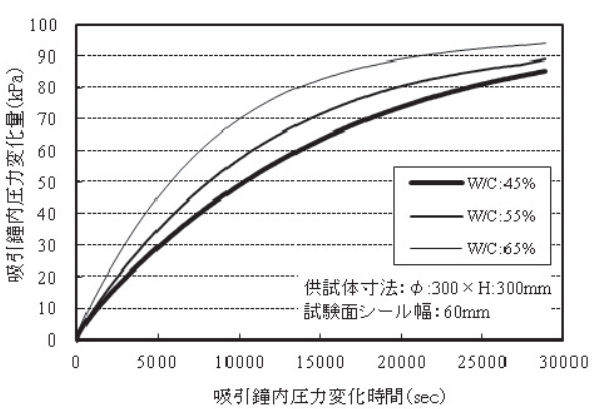

図 2 吸引鐘内の圧力変化時間と圧力変化量

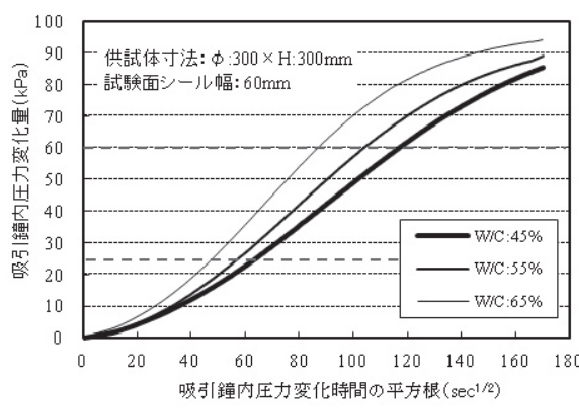

図 3 圧力変化時間の平方根と圧力変化量

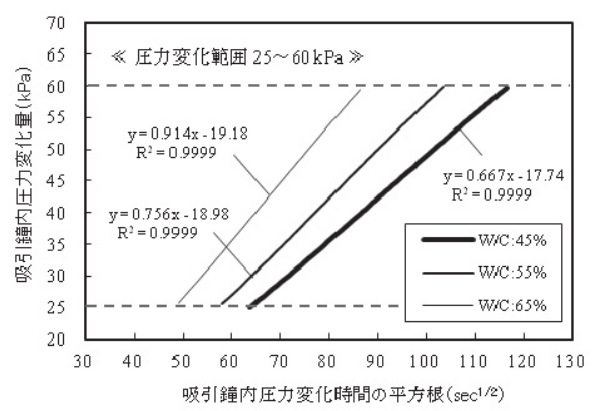

図 4 圧力変化量 $25 \sim 60 \mathrm{kPa}$ の範囲における 圧力変化時間の平方根と圧力変化量
相当)において, 両者の間に直線関係が認められる。図 4 は, 上記の 圧力範囲における両者の関係を抽出したものであるが, この範囲に おける両者の直線関係は極めて良好である。このことから, 本研究 では, 圧力低下量 $25 \sim 60 \mathrm{kPa}$ の範囲における圧力変化時間の平方根 と圧力変化量の関係から求まる值を簡易透気係数 $\alpha$ とし, 簡易透気 試験における透気性指標值として扱うこととした。

簡易透気係数 $\alpha\left(\mathrm{kPa} / \mathrm{sec}^{1 / 2}\right)$ は, 式(1)により算出寸る。

$$
\Delta P=\alpha \sqrt{T}
$$

ここに, $\Delta P$ : 圧力低下量 $(\mathrm{kPa}), T$ : 圧力低下時間 $(\mathrm{Sec}$.

\section{2 今本らの透気試験法 ${ }^{15)}$}

今本らの方法は，著者らが検討している簡易透気試験法と原理的 に大きな違いはないが, 吸引鐘の設置方法や計測圧力範囲, 透気性 指標値の算出方法に相違点がある。

今本らが提案する試験方法の手順 ${ }^{15)}$ を以下に示す。

1）試験位置において静電容量を測定する。

2） $2 \mathrm{~cm}$ 幅のシリコンリング（内径 $11.5 \mathrm{~cm} ）$ を酶酸ビニル樹脂によ り接着する。

3）シリコンリング上へ吸引鐘（セパラブルカバー：内径 $12.0 \mathrm{~cm} ）$ を装着する。

4）吸引（排気速度 : $20 \mathrm{~L} / \mathrm{min}$ ）および $16.0 \sim 33.3 \mathrm{kPa}$ (大気圧との差に 換算すると約 $-85 \mathrm{kPa} \sim-68 \mathrm{kPa}$ ) の気圧変化に要する時間 $\mathrm{T}$ を測定 し，透気指数 A.P.I.を式(2)により算出する。

5）試験位置で静電容量を再度測定する。透気試験前後において含 水率指示值に顕著な差がなければ，含水率の影響は無視する。

$$
\text { A.P.I.(Air Permeability Index) }=\frac{33.3-16.0}{T}
$$

ここに，T：33.3〜16.0kPaにおける経過時間（Sec.）

\section{3 トレント透気試験法 ${ }^{20)}$}

トレント透気試験は, 図 5 に示すように, 内部と外部に 2 つの室 を持つチャンバーを用いるダブルチャンバー法に分類される。外部 チャンバーと内部チャンバーの圧力バランスを等しく制御すること により, 表層脆弱層を介して外部から内部チャンバーへ流入する空 気流を物理的に排除し，内部チャンバー下において，室内試験と同 様の一軸方向の透気経路を再現した方法である。透気性を評価する ためのベンチマーク試験である RILEM-CEMBUREAU 法 ${ }^{22)}$ とほぼ一 致する空気流を原位置試験で実現したとされる試験法である。

トレント透気係数 $K_{T}\left(\mathrm{~m}^{2}\right)$ は, チャンバー内部の圧力変化とその 時間を測定することにより，理論式(3)によって算定される。
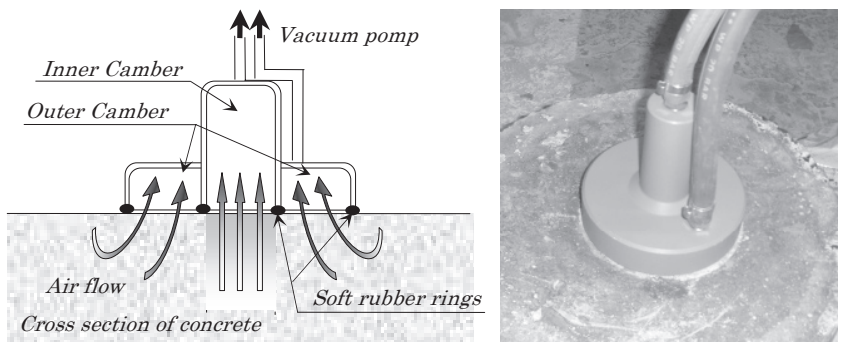

図 5 トレント透気試験法の概要 ${ }^{20)}$

表 1 コンクリートの調合

\begin{tabular}{c|c|c|c|c|c|c|c|c}
\hline \hline W/C & \multirow{2}{*}{$\begin{array}{c}\text { Sl. } \\
(\%)\end{array}$} & \multirow{2}{*}{$\begin{array}{c}\text { Air } \\
(\%)\end{array}$} & \multirow{2}{*}{$\begin{array}{c}\text { s/a } \\
(\%)\end{array}$} & \multicolumn{6}{|c}{ 単位量 $\left(\mathrm{kg} / \mathrm{m}^{3}\right)$} \\
\cline { 5 - 8 } & & & & $\mathrm{W}$ & $\mathrm{C}$ & $\mathrm{S}$ & $\mathrm{G}$ & $\mathrm{AWR}^{* 1}$ \\
\hline \hline 45 & 84 & 4.1 & 40.2 & 162 & 360 & 699 & & 2.12 \\
\hline 55 & 81 & 4.2 & 42.3 & 160 & 291 & 761 & \multirow{6}{*}{1181} & 1.72 \\
\hline 65 & 72 & 4.1 & 43.4 & 160 & 246 & 797 & & 1.45 \\
\hline
\end{tabular}

$$
K_{T}=4\left(\frac{V_{C}\left(d P_{I} / d t\right)}{A\left(P_{a}^{2}-P_{I}^{2}\right)}\right)^{2} \frac{\mu P_{a}}{\varepsilon} \int_{t_{a}}^{t}\left[1-\left(\frac{P_{I}}{P_{a}}\right)^{2}\right] d t
$$

ここに, $V_{C}$ : 内部チャンバーと接続エレメント(ホース)の容積 $\left(\mathrm{m}^{3}\right)$, $A$ : 内部チャンバー下で生じると仮定される一軸方向の空気流の断 面積 $\left(\mathrm{m}^{2}\right), \mu$ : 空気の動粘度 $\left(\mathrm{Ns} / \mathrm{m}^{2}\right), \varepsilon$ : 所与のコンクリート空 隙量 $\left(\mathrm{m}^{3} / \mathrm{m}^{3}\right), P_{I}$ : 内部チャンバー内圧力 $\left(\mathrm{N} / \mathrm{m}^{2}\right), P_{a}$ : 大気圧 $\left(\mathrm{N} / \mathrm{m}^{2}\right)$

\section{4. 簡易透気試験法の基本特性と適用条件（実験シリーズ I ） \\ 4.1 実験概要}

\section{（1）使用材料および調合}

使用材料として, 普通ポルトランドセメント (密度 : $\left.3.16 \mathrm{~g} / \mathrm{cm}^{3}\right)$, 輝緑岩砕石 (Gmax : $20 \mathrm{~mm}$, 表乾密度 $: 2.93 \mathrm{~g} / \mathrm{cm}^{3}$, 実績率 : $\left.57.0 \%\right)$, 石灰岩砕砂（表乾密度 : $2.58 \mathrm{~g} / \mathrm{cm}^{3}$, F.M. : 2.65）を使用した。練り 混ぜ水は一般水道水とし，混和剂にはリグニンスルホン酸塩を主成 分とする $\mathrm{AE}$ 減水剂を用いた。コンクリートの調合を表 1 に示す。 水セメント比は $45 \%, 55 \%$ および $65 \%$ の 3 水準とし, 目標スランプ および目標空気量は，それぞれ $80 \mathrm{~mm} ， 4.5 \%$ とした。なお，実験シ リーズ I では，供試体数が多く，大量のコンクリートを使用するこ とからレディーミクストコンクリートを用いることとした。

（2）供試体作製および養生方法

表 2 に供試体寸法・数量および各検討項目における使用供試体を 示す。供試体は全て円柱形状とし，その円形端部を簡易透気試験の 測定対象面とした。コンクリートの透気性は，表層品質のばらつき 
や久陥の存在を敏感に反映するため, 表面仕上げやブリーディング による表層組織の不均質性による影響を考慮し, また, 実構造物の 一般的な壁面と対応寸るように，測定対象面となる円形端部は型枠 に接する打設側面となるように作製した。図 6 に供試体の打設方法 を示す。養生は材齢 7 日までの散水養生とし, 養生終了後, 材齢 91 日まで室内静置した。コンクリートの透気性は, 測定対象面の含水 状態に大きく影響されることが指摘されている ${ }^{7)}$ 。そこで, 簡易透 気試験の開始時期の決定にあたり, 材齢 14 日以降, 水セメント比 毎に無作為に選定した 3 体の供試体を対象に, 静電容量押し当て式 水分計 (計測可能範囲 : 水分率 $0 \sim 15 \%$ ) を用いて表面水分率の測定 を行った。図 7 に表面水分率の測定結果を示寸。初期材齢では全般 に高い值を示し，材齢の経過に伴い水分率は徐々に低下寸る傾向を 示す。材齢 70 日以降, 水分率の低下は緩慢となり $4.0 \sim 4.5 \%$ 範囲

表 2 供試体寸法・数量および各検討項目に対応する供試体 (○印)

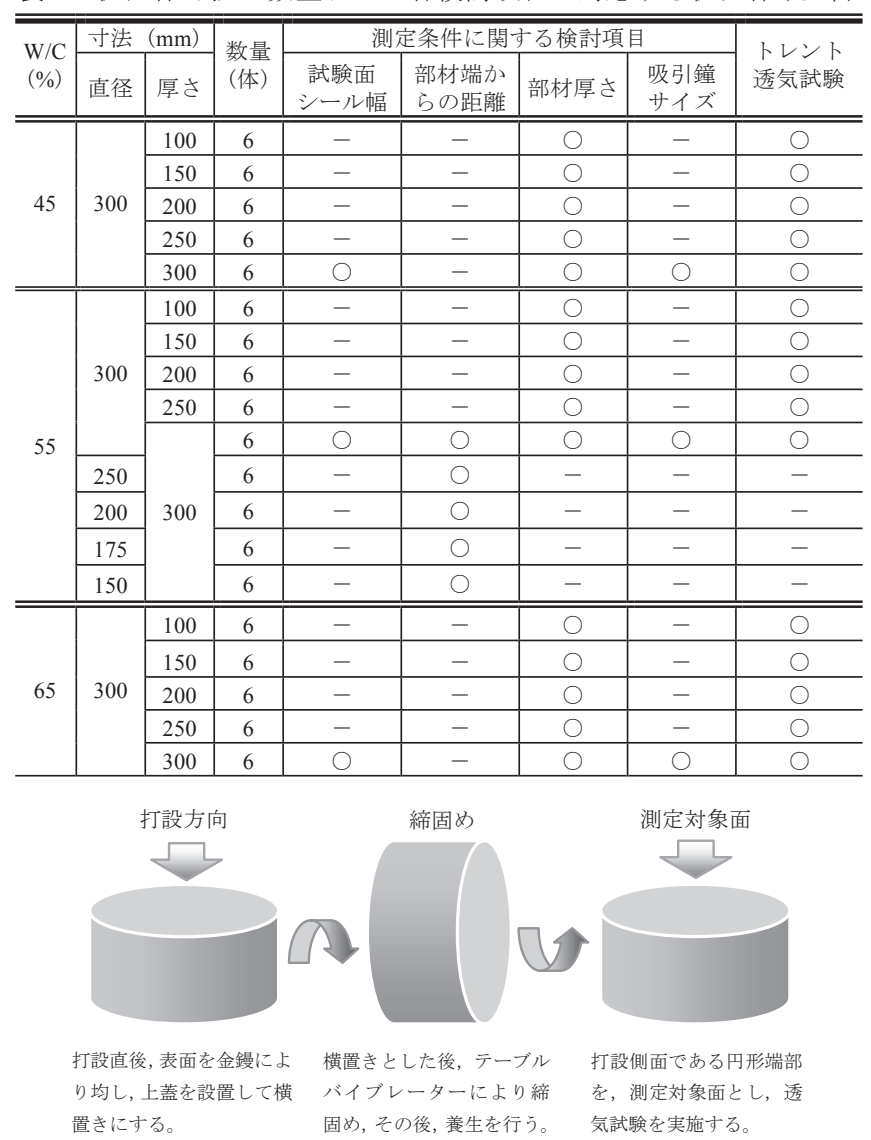

図 6 供試体の打設方法(打設方向，締固めおよび測定対象面）

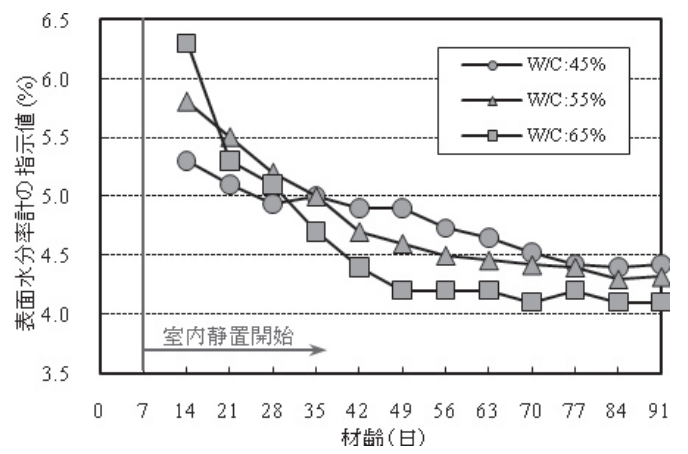

図 7 実験室内に静置した供試体の表面水分率の経時変化
でほぼ定常状態となった。本研究ではこの結果を踏まえ，材齢 91 日以降，表面水分率が $4.5 \%$ 以下の状態で簡易透気試験を実施した。

\section{2 実験結果および考察}

\subsection{1吸引鐘外周の試験面シール幅が透気性指標值に及ぼす影響}

吸引鐘外周における試験面シールの幅の違いは，シール外周の透 気経路に相違を生じさせ，透気性指標值に影響を及ぼすと考えられ る。そこで, $\phi 300 \mathrm{~mm} \times 300 \mathrm{~mm}$ の供試体 (表 2 参照) を対象に，シー ル幅を $15,30,45,60 \mathrm{~mm}$ と段階的に変化させた透気試験を実施し， シール幅が透気性指標值に及ぼす影響について検討した。なお，今

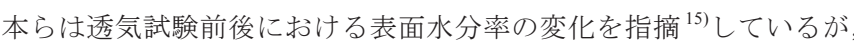
本実験においては，シール幅拡張後の測定が連続したものとならな いよう計測間隔を開けるとともに, 試験前に表面水分率を計測し, 各々の計測時における差がないことを確認した後に試験を行った。

図 8 は，水セメント比 $45 \%, 55 \%$ よび $65 \%$ におる吸引鐘外周 の試験面シール幅と簡易透気係数の関係を示したものである。いず れの水セメント比においても，シール幅の段階的な拡張により，簡 易透気倸数は低下寸る傾向を示す。これは, シール材として使用し たシリコンパテ外周からの空気流入がシール幅の拡張により制限さ
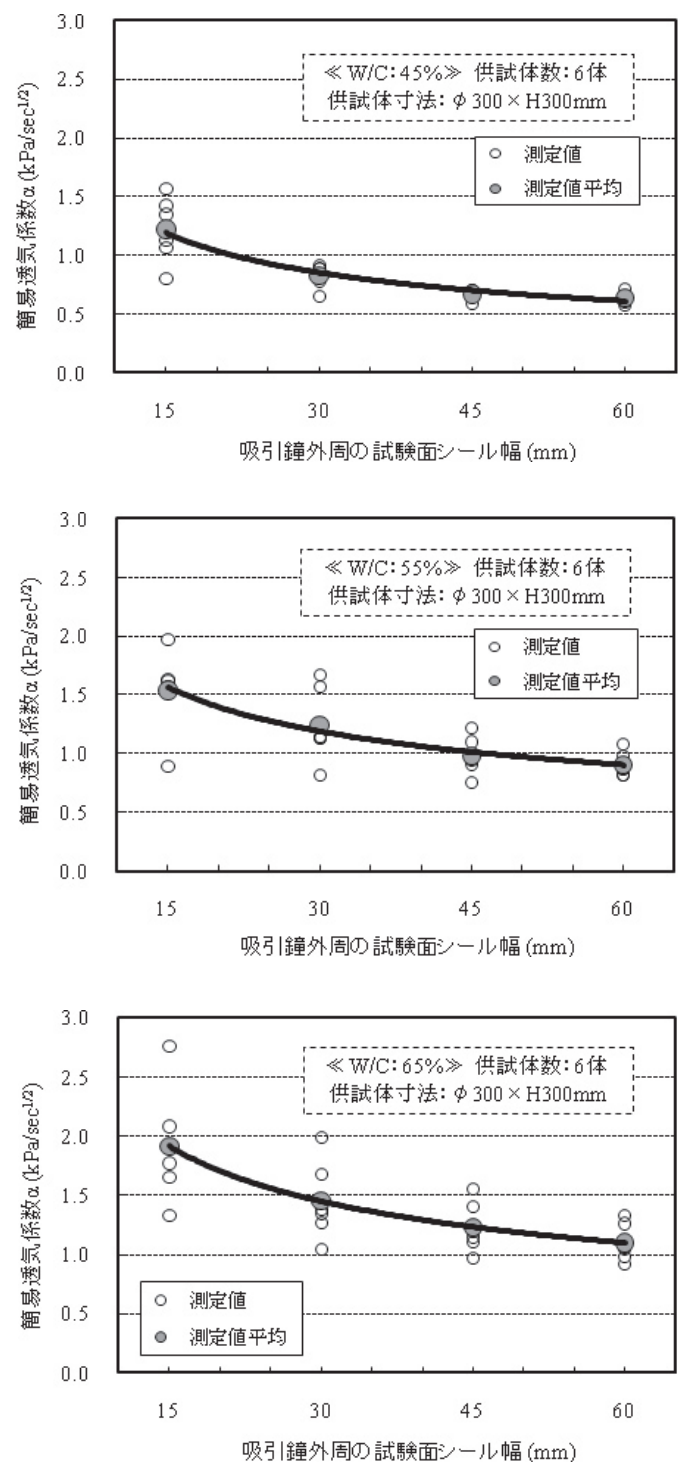

図 8 吸引鐘外周の試験面シール幅と簡易透気係数の関係 
れたためと考えられる。また, 水セメント比の増加に伴い簡易透気 係数も増加傾向を示すが, これは, 水セメント比によるコンクリー 卜組織の緻密性に起因するものであり, 表層部の品質や欠陥の有無 を敏感に反映する透気試験の特徴を示す。しかし, 本試験法と同様 に吸引鐘を用いた透気試験法である今本らの方法では, シール幅(今 本らの論文 ${ }^{15)}$ では[遮断幅] と定義)を 20〜30 mm 以上としても，透 気指数に大きな変化は見られないとしている。ここで両者の計測圧 力範囲に着目すると, 今本らの方法は, 吸引鐘内の圧力が大気圧と の差で約-85〜-68kPa の範囲において透気指標を算出しているのに 対し，本試験法では-97kPa〜0kPa までの範囲で計測を行い，-72〜 $-37 \mathrm{kPa}$ に相当する範囲で透気係数を算出している。吸引式の透気試 験の場合, まず, 吸引鐘直下からの空気流入が生じ, その後, 吸引 圧力や圧力回復に要する空気の総量に応じて段階的に透気領域を拡 大していくと仮定すれば, 本試験法は, 今本らの方法と比較して約 $12 \mathrm{kPa}$ 高い吸引圧力を作用させており, 透気係数の算出領域も今本 らのそれと比較して吸引鐘内の圧力が低い領域にある。また，使用 する吸引鐘のサイズも異なり, 吸引鐘内の圧力回復に要する空気量 も異なる。これらの要因により, 本試験法ではシール幅を $20 \sim 30 \mathrm{~mm}$ 以上にした場合においても, 透気係数の低下が見られたものと考え られる。この計測圧力範囲と透気領域の関係については, 供試体に 歪ゲージを埋設するなどして, 今後詳細に検討を加える必要がある。

図 9 は, 試験面シール幅と簡易透気係数の変動係数を示したもの であるが，シール幅を拡張することにより変動係数は小さな值を示

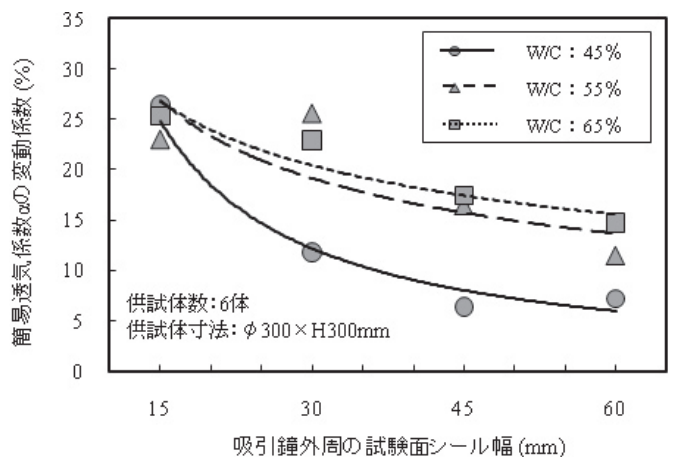

図 9 試験面シール幅の相違による簡易透気係数の変動係数
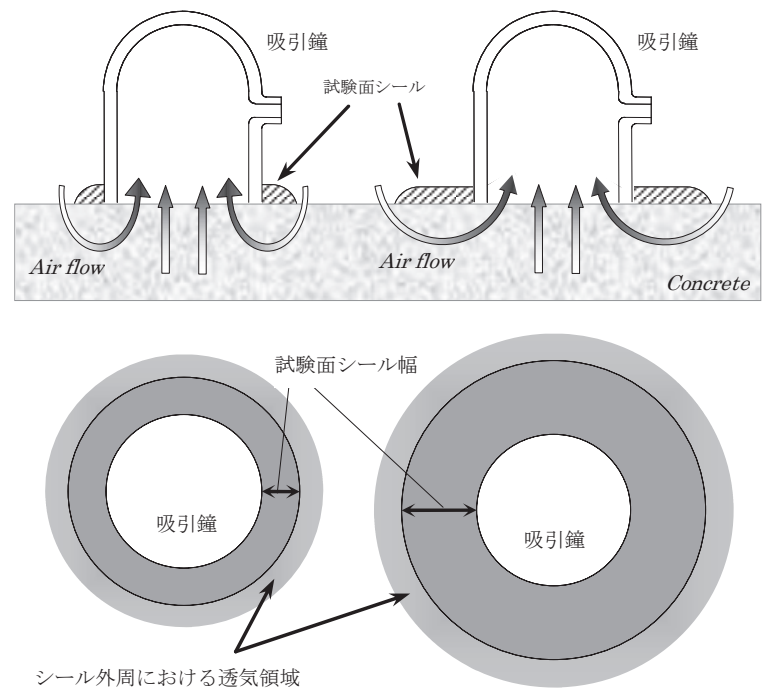

図 10 試験面シール幅が透気経路および透気領域に及ぼす影響
した。これは, シール幅の拡張によりシールの確実性が増すことが 要因の一つとして考えられるが, 図 10 に示すように, シール幅が小 さい場合ではシール外周の透気面積が少なくなり，極めて部分的な 組織の粗さなどの欠陥による影響が反映されるために変動係数が大 きくなり，シール幅が大きい場合ではシール外周の透気面積が増加 するためにデータのばらつきが減少する可能性も考えられる。本実 験の範囲ではシール幅 $60 \mathrm{~mm}$ を採用することで，水セメント比 $65 \%$ においても簡易透気係数の変動係数は $20 \%$ 以下の值を示した。簡易 法による透気性指標值の変動係数については, 概ね $30 \%$ 程度である

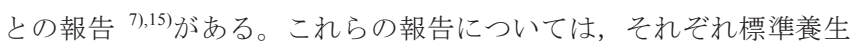
(材齢 28 日水中養生) 供試体の打設底面を対象とした場合および材 齢 4 ケ月の実大壁を対象とした場合の知見であり，本研究の実験条 件とは異なる。しかし，養生条件や試験材齢等の一部条件について は，本実験の方がより厳しい条件を設定しており，試験の信頼性の 観点から，簡易透気試験法の有用性は認められるものと思われる。

本研究では, シール幅を $60 \mathrm{~mm}$ 以上に設定した実験を行っていな いため, さらにシール幅を拡張した場合の試験精度については未確 認である。しかし，シール材の設置や除去といった試験の作業性や 簡易性を考慮し，本実験の範囲で最も試験精度を確保できることが 確認されたシール幅 $60 \mathrm{~mm}$ を設定し，以降の測定に採用した。

\subsection{2 部材端部から測定位置の距離が透気性指標値に及ぼす影響}

図 11 に示すように, コンクリート部材端部から測定位置までの距 離の相違は，簡易透気係数に影響を及ぼす可能性がある。そこで， 部材厚さを $300 \mathrm{~mm}$ 一定として, 直径を $\phi 175 \mathrm{~mm}, 200 \mathrm{~mm}, 250 \mathrm{~mm}$, $300 \mathrm{~mm}$ と変化させた供試体 (表 2 参照)について簡易透気試験を実施 した。吸引鐘の設置位置は供試体円形端部の中心とし，これにより 部材端部から吸引鐘中心までの距離は供試体直径の $1 / 2$ となる。な お，試験面シール幅は原則 $60 \mathrm{~mm}$ とするが $\phi 300 \mathrm{~mm}$ 以外の供試体 については, 試験面が小さく吸引鐘外周から部材端部までの距離が $60 \mathrm{~mm}$ 以下となるため, 吸引鐘外周の試験対象面全面をシールした。

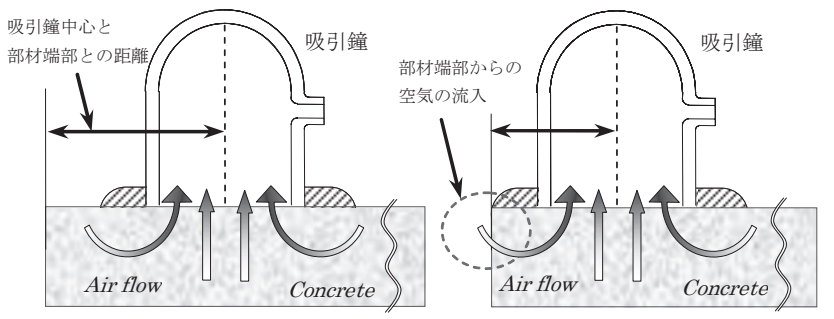

図 11 部材端部から測定位置の距離が透気経路に及ぼす影響

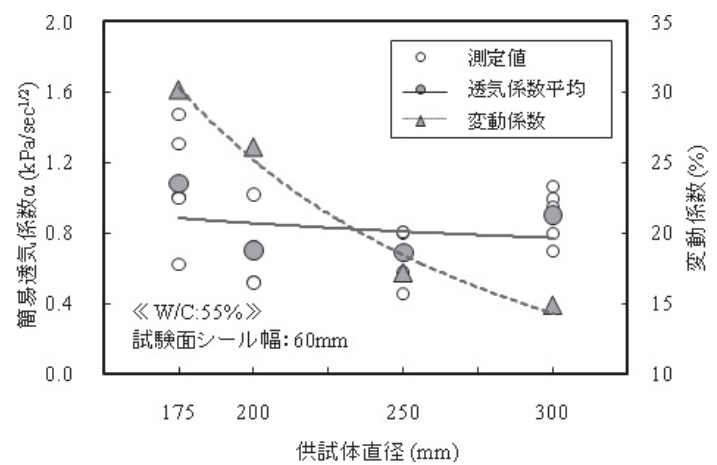

図 12 直径の異なる供試体の簡易透気係数とその変動係数 
図 12 は, 直径の異なる供試体について得た簡易透気係数とその 変動係数を示したものである。 $\phi 175,200,250 \mathrm{~mm}$ の供試体におけ る簡易透気係数は, 直径の増加に伴い減少傾向を示した。これらの 供試体については, 吸引鐘外周の試験対象面を全てシールしている ため, 空気の流入経路として考えられるのは供試体側面および底面 からの流れである。供試体高さが統一されていることを考慮すると， 部材端部からの距離の増加により供試体側面からの空気流入が抑 制され，簡易透気係数を低下させたものと思われる。ここで，減少 傾向を示した $\phi 175 \sim 250 \mathrm{~mm}$ について, 簡易透気係数の減少が有意 なものであるかを検証するため, それぞれの試験で得られた簡易透 気係数を対象に $\mathrm{t}$ 検定を行った。その結果, $\phi 175 \mathrm{~mm}$ から $200 \mathrm{~mm}$ に変化させた場合の簡易透気係数の減少については「 $\mathrm{t}(9)=2.599, \mathrm{p}$ <0.05」で有意差が認められた。しかし， $\phi 200 \mathrm{~mm}$ から $250 \mathrm{~mm}$ に 変化させた場合については「 $\mathrm{t}(9)=0.349, \mathrm{p}>0.1 」$ となり, 統計学的 に有意な差は認められなかった。以上より， $\phi 200 \mathrm{~mm}$ (部材端部か ら測定位置までの距離：100mm) 以上とすることで部材端部からの 距離の影響を無視できるものと思われるが， $\phi 300 \mathrm{~mm}$ 供試体におい て簡易透気係数の増加が見られた。 $\phi 300 \mathrm{~mm}$ 供試体については、試 験面シール幅を $60 \mathrm{~mm}$ としているため, 供試体側面からの空気流入 に加え, シール外周からの流れが加わり, 簡易透気係数が増加した ものと思われる。これは, シール幅を $60 \mathrm{~mm}$ 以上に拡張することに よる試験精度の向上を示唆寸るもので, 今後, 透気領域や計測圧力 範囲との関連も含めた詳細な検討により明らかにする必要がある。

部材端部からの距離と簡易透気係数の変動係数の関係に着目した 場合, 距離の増加に伴い変動係数は減少寸る傾向を示し, $\phi 300 \mathrm{~mm}$ の供試体においては約 $15 \%$, 既往の研究成果 ${ }^{77,15)}$ と比較しても, 高い試験精度を有すると判断できる。これは, 部材端部から測定位 置までの距離を長くすることで空気の流入経路が限定され，特に， 部材端部の欠陥を介した非定常な空気流入が抑制された結果と考え られ, 部材端部からの距離を $150 \mathrm{~mm}$ 以上とすることで試験精度を 向上させることができる可能性を示唆する。

以上の結果より, 簡易透気試験法の適用においては, 試験精度を 重要視し, 部材端部から測定位置 (吸引鐘中心)までの距離を $150 \mathrm{~mm}$ 以上とすることが望ましいと思われる。

\subsection{3 コンクリートの部材厚さが透気性指標値に及ぼす影響}

部材厚さが簡易透気係数一及ぼす影響について検討するため, 直 径を $\phi 300 \mathrm{~mm}$ 一定とし, 部材厚さを 100, 150, 200, 250 および $300 \mathrm{~mm}$ に変化させた供試体 (表 2 参照)を対象に簡易透気試験を実施した。

図 13 は，部材厚さと簡易透気係数の関係を示したものである。 当初, 部材厚さの減少に伴い供試体底面からの空気流入が生じ, 簡 易透気係数は増加すると想定されたが, 簡易透気係数は, 部材厚さ が薄いものほど減少する傾向を示した。なお，今本らの論文 ${ }^{15}$ にお いても，本文における記述はないが，供試体が厚くなると透気指数 は増加する傾向にあることが論文中の図 $2^{15)}$ に示されており, 本実 験と同様の結果が得られている。これらの要因として, 供試体側面, 或いは, シール外周からの空気流入による影響が考えられる。しか し, 前述の通り, 試験面におけるシール幅を $60 \mathrm{~mm}$ とし, 部材端部 までの距離を $150 \mathrm{~mm}$ 以上確保することで, 変動係数が減少するこ と確認しており，これらの条件を満たす本実験では，変動係数の増 加要因となる供試体側面およびシール外周からの非定常な空気流

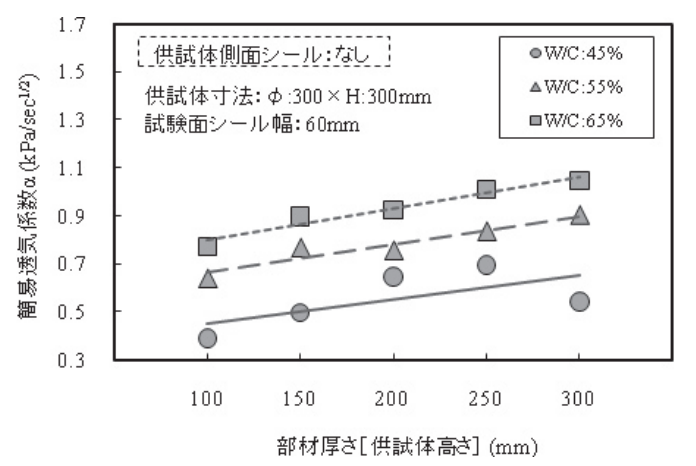

図 13 部材厚さと簡易透気係数の関係［側面シールなし］

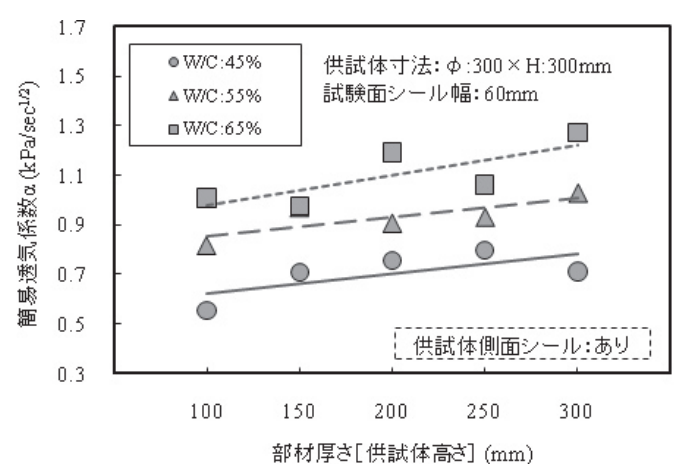

図 14 部材厚さと簡易透気係数の関係［側面シールあり］

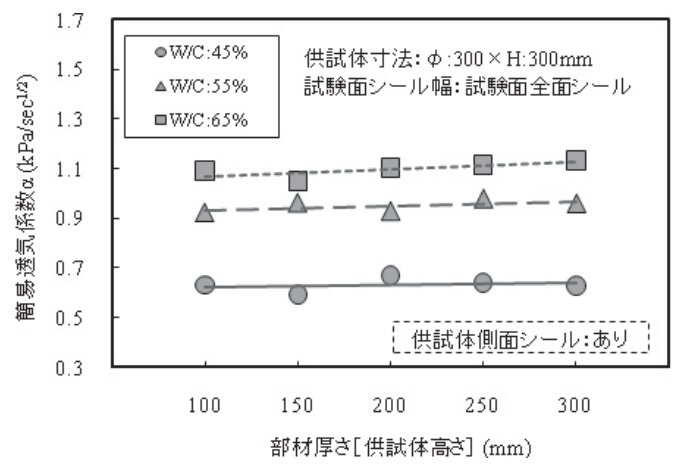

図 15 部材厚さと簡易透気係数 [供試体側面·試験面シール]

入は抑制されているものと思われる。そこで，部材厚さと簡易透気 係数の関係を明らかにするため, 供試体側面をシリコーンシーラン トによりシールし，供試体側面からの空気流入を完全に遮断した状 態での追加試験を実施した。

図 14 に追加試験の結果を示す。供試体側面からの空気流入を遮断 しても, 部材厚さの減少に伴い簡易透気係数が減少する傾向に変化 は見られなかった。図 13 および図 14 を比較すると, 簡易透気係数 の全体的な増加が見られるが，この傾向は両実験の試験材齢が大き く異なることに起因寸るものと思われる。図 13 の実験については, 本研究で実施した他の実験と同様に材齢 91 日以降に順次計測を開 始したが, 図 14 の実験については, 追加試験という性格上, 材齢約 9 ケ月という時期に実施した。したがって, 各供試体表面の平均水 分率もそれぞれ $4.3 \%, 3.1 \%$ と大きく異なり, 後者については, 測定 時期の違いに起因した季節的な気温変動や湿度変動によって, 空気 の密度や粘性に変化を生じたことも影響しているものと考えられる。 このことから，本試験法の実構造物への適用にあたっては，外気温 


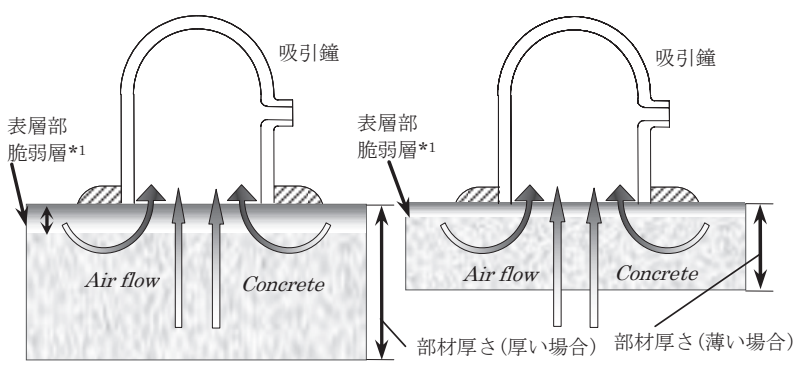

*1 部材厚さにより, 形成される脆弱層の厚さや脆弱度が異なると考えられる。

図 16 部材厚さの違いによる透気経路および表層脆弱層の形成

や湿度等の環境要因による影響についても十分に検討する必要があ るものと思われる。その他, 図 14 における簡易透気係数の増加要因 としては, 供試体側面からの空気流入を遮断したことにより透気領 域に変化が生じ, 吸引圧力の及びや寸い試験面シール外周からの空 気流入が増加した可能性も考えられるが確認を要する。結果的に, 本追加実験からは, 部材厚さの違いに起因した傾向の要因を明らか にする情報は得られなかった。図 15 は, 側面を完全にシールした上 記の供試体に対し,さらに試験対象面 (吸引鐘外周) 全面をシールし, 供試体底面のみが外気に露出した状態で実施した試験の結果である。 供試体側面および試験対象面を完全にシール寸ることで, 部材厚さ に起因する試験值の変化は小さくなり, ほぼ一定の值を示した。こ のことから, 簡易透気係数は, 測定対象面からの空気流入による影 響が卓越し, 部材厚さの違いによる影響は極めて小さいと考えられ る。しかし, 図 14 および図 15 を比較すると, 簡易透気係数は試験 対象面を全面シール寸ることにより, 部材厚さの小さいものでは増 加，部材厚さの大きいものでは減少する様相が見られる。これは, 部材の薄い場合では試験対象面における透気経路を遮断することに より透気領域が変化し，この透気領域の変化に伴い部材背面からの 空気流入が生じて透気係数が増加した可能性が考えられる。また, 部材の厚い場合においても同様の現象が生じるものと思われるが, 部材背面までの透気経路が長いために部材背面からの空気流入は少 なく, 試験対象面からの空気流入を遮断したことによる影響が卓越 して, 結果的に, 透気係数が低下した可能性が考えられる。

以上を総合的に判断すると, 部材厚さの違いに起因する部材背面 からの空気流入による影響は小さく, 部材厚さの違いによる透気性 の変化は, コンクリート表層に形成される脆弱層(図 16)を介したシ 一ル外周からの空気流入に依存するものと考えられる。この点につ いて著者らは, 別途, 部材厚さの相違が表層部脆弱層の形成に及ぼ 寸影響として検討を進めている ${ }^{23)}$ 。これらの検討から, 部材厚さの 増加に伴いブリーディング量が増加することや、その現象は型枠近 傍において最も顕著となることを明らかにしており，コンクリート 表層部に形成される脆弱層の厚さや脆弱度は, 部材断面の厚さに起 因する可能性があることを示している。

\subsection{4吸引鐘のサイズが透気性指標値に及ぼす影響}

現位置で実施可能な透気試験には, 簡易的であり, かつ迅速な評 価が可能であることが要求される。簡易透気試験に用いる吸引鐘を 小型化して吸引容積を少なくすることにより, 減圧した吸引鐘内の 圧力が大気圧に戻るために要する時間は短くなり, 簡易透気試験法 の迅速化が可能となるものと思われる。そこで, 吸引鐘のサイズ変 更が簡易透気係数に及ぼす影響について検討を行った。写真 2 にサ

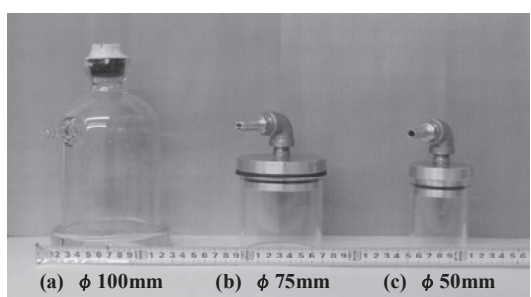

写真 2 簡易透気試験に用いたサイズの異なる吸引鐘

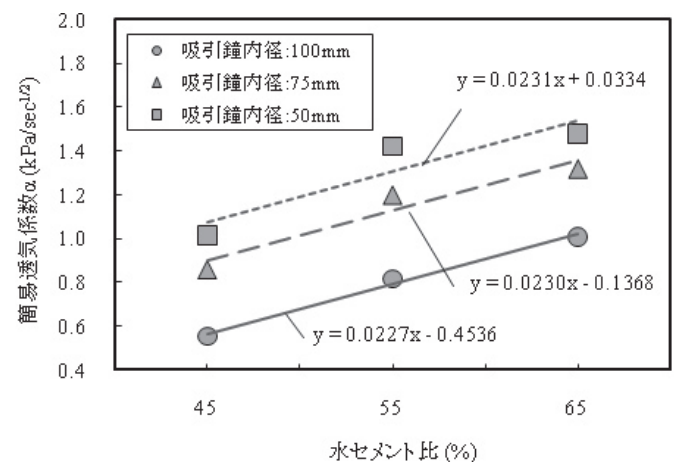

図 17 吸引鐘を小型化した場合の水セメント比と簡易透気係数

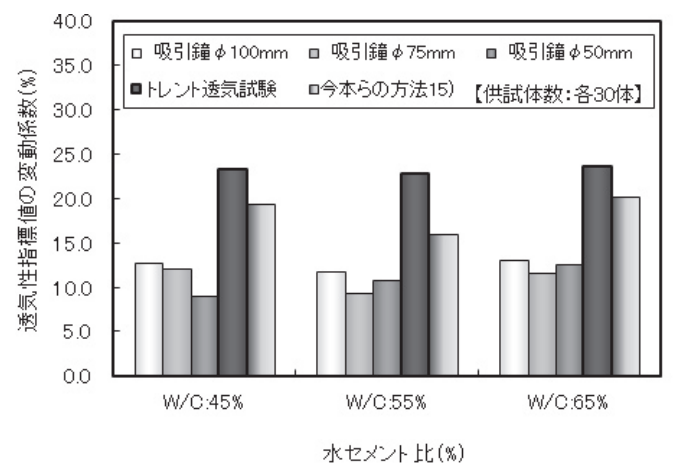

図 18 各透気試験法における透気性指標値の変動係数

イズの異なる 3 種類の吸引鐘を示す。（a）は内径 $100 \mathrm{~mm}$ [内容積 : $1015 \mathrm{cc}$ ]，（b）は内径 $75 \mathrm{~mm}$ [内容積：295cc]，（c）は内径 $50 \mathrm{~mm}$ [内容 積：135cc]の吸引鐘である。なお，対象供試体は $\phi 300 \mathrm{~mm} \times$ 部材厚 さ $300 \mathrm{~mm}$ の供試体 (表 2 参照) とし, 試験面シール幅は, 吸引鐘の サイズに関わらず，全てのケースにおいて $60 \mathrm{~mm} の 一$ 定とした。

図 17 に, 内径 $\phi 75 \mathrm{~mm}, 50 \mathrm{~mm}$ の小型吸引鐘を用いた場合の簡易 透気係数と水セメント比の関係を, $\phi 100 \mathrm{~mm}$ の吸引鐘を用いた場合 を含めて示す。図 17 より， $\phi 100 \mathrm{~mm}$ の吸引鐘を用いた場合と比較 し， $\phi 75 \mathrm{~mm} ， \phi 50 \mathrm{~mm}$ に小型化した場合, 簡易透気係数は増加傾向 を示す。これは，吸引鐘の小型化に伴い吸引鐘の内容積が少なくな り, 吸引圧力の回復時間が短くなるためと考えられる。ここで, 吸 引鐘の内容積に接続ホースの内容積 (内径 $\phi 8 \mathrm{~mm} \times 700 \mathrm{~mm}$ として概 算)を加算し, 圧力作用面積で除すことで得られる值を単位面積あた りの回復空気量 (大気圧に戻るために必要な空気量) と寸ると，それ ぞれ $0.134(\phi 100 \mathrm{~mm}), 0.075(\phi 75 \mathrm{~mm}), 0.087(\phi 50 \mathrm{~mm})$ となる。 さらに, この回復空気量の逆数をとり， $\phi 100 \mathrm{~mm}$ を 1 とした比率を 示すと，それぞれ $1.78(\phi 75 \mathrm{~mm}) ， 1.54(\phi 50 \mathrm{~mm})$ となる。簡易透気 係数の増加率平均は， $\phi 100 \mathrm{~mm}$ を 1 とした場合，それぞれ $1.44(\phi$ $75 \mathrm{~mm}), 1.68(\phi 50 \mathrm{~mm})$ であり, この両者を比較すると, 明確な対応 は得られないものの, 吸引鐘容積および圧力作用面積が透気係数の 
増加に影響を及ぼしていることは明らかである。このことから，さ らに透気領域や作用圧力の影響を加味することで, 吸引鐘や接続要 素の形状によらない一般值としての透気係数を算出できる可能性が 示唆される。また, 吸引鐘を小型化した場合の簡易透気係数と水セ メント比との関係は， $\phi 100 \mathrm{~mm}$ の吸引鐘を用いたときに得られる傾 向とほぼ等しく, 各々の近似式の回帰係数は概㸚 0.023 と同じ值を 示す。このことから, 吸引鐘サイズを変更しても, 水セメント比の 違いによる透気性を相対的に評価することが可能であると思われる。 吸引鐘を小型化した場合の計測時間については, $\phi 100 \mathrm{~mm}$ の吸引 鐘を用いた場合と比較し, $\phi 75 \mathrm{~mm}$ の場合で約 5 割, $\phi 50 \mathrm{~mm}$ の場 合で約 3 割まで短縮された。なお, 簡易透気試験の試験時間は, 試 験装置のセッティング等を含むと約 $2 \sim 4$ 時間程度 (吸引鐘 $\phi 100 \mathrm{~mm}$ の場合)を要するが, 今本らの方法 ${ }^{15)}$ では 5 分程度, トレント法 ${ }^{20)}$ では 20〜30 分程度である。このことから, 今本らやトレントの提案 寸る方法は極めて簡易的な方法であると言える。本試験においても， 吸引鐘の小型化や計測圧力範囲の限定により, 試験時間の短縮を図 ることは可能であるが, 試験精度を優先した場合, 計測する圧力範 囲を限定せず包括的に採取した実験值を基に評価・判断することも 重要と思われる。次に，簡易透気係数の変動係数について述べる。

図 18 に, 吸引鐘サイズを変更した場合の簡易透気係数の変動係数 を示す。また, 試験精度に関する比較を行うため, トレント法 ${ }^{20}$ に よる透気性指標值の変動係数と本報で検討している簡易透気試験装 置を用いて得た測定值を今本らの方法 (式 (2) $)^{15}$ )で処理した透気指 数の変動係数を併せて示した。ここで示寸変動係数は， $\phi 300 \mathrm{~mm}$, 部材厚さ $100,150 ， 200 ， 250 ， 300 \mathrm{~mm}$ の供試体各 6 体について算 出した変動係数を, 各水セメント比の平均として示したものである。 なお, 各試験法の変動係数を部材厚さ毎に比較した場合においても, 序列関係はほぼ同様の傾向を示す。基準となる $\phi 100 \mathrm{~mm}$ の吸引鐘を 用いた試験では変動係数 11〜 14\%という值が得られた。 $\phi 75 \mathrm{~mm}$, $\phi 50 \mathrm{~mm}$ と吸引鐘を小型化した試験における変動係数については, 全体的に 9〜13\%の範囲にあり， $\phi 100 \mathrm{~mm}$ の吸引鐘を用いた場合と ほぼ同程度の值が得られた。これは, 吸引鐘を小型化した場合にお いても試験精度を確保できることを示唆するものと考えられる。一 方, 比較対象として実施したトレント法では変動係数 22 24\%, 今 本らの方法により測定值を処理した場合では 16〜20\%という值を得 た。以上の結果から, 本試験法は, 簡易性の観点から試験時間に課 題を残すものの, 既存の試験法と比較して良好な試験精度を有する という点で, その有用性は認められるものと思われる。

\subsection{5 トレント透気試験法による透気係数と簡易透気係数の関係}

図 19 に, トレント透気係数と簡易透気係数の関係を示寸。これは, $\phi 300 \mathrm{~mm}$, 部材厚さ $100 ， 150 ， 200 ， 250,300 \mathrm{~mm}$ の 5 水準の供試 体 (表 2 参照) を対象に, トレント透気試験 ${ }^{20}$ および簡易透気試験を 実施した結果を比較したものである。両試験法により得られた透気 性指標值の関係からは約 0.81 という決定係数が得られ, 両者は比較 的よく対応していると思われる。トレント透気試験法は，近年，簡 易型の原位置透気試験法として適用実績が多く, さらに, RILEM が 透気性評価のためのベンチマーク試験法として位置づける RILEM CEMBUREAU 法 ${ }^{22)}$ とほぼ一致する空気流を原位置試験おいて実現 した試験法である。このことからトレント透気試験法との対応は, 本研究で検討寸る簡易透気試験の有用性を示寸ものと思われる。

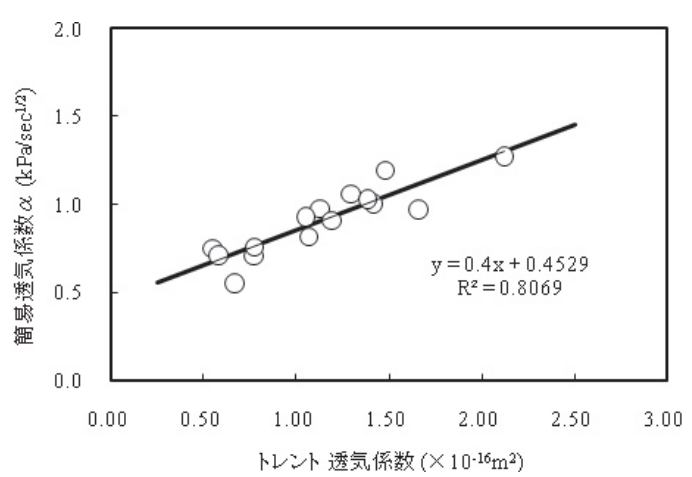

図 19 トレント透気係数と簡易透気係数との関係

表 3 コンクリートの調合

\begin{tabular}{c|c|c|c|c|c|c|c}
\hline \hline \multirow{2}{*}{$\begin{array}{c}\mathrm{W} / \mathrm{C} \\
(\%)\end{array}$} & \multirow{2}{*}{$\begin{array}{c}\mathrm{S} l . \\
(\mathrm{mm})\end{array}$} & \multirow{2}{*}{$\begin{array}{c}\mathrm{s} / \mathrm{a} \\
(\%)\end{array}$} & \multicolumn{6}{|c}{ 単位量 $\left(\mathrm{kg} / \mathrm{m}^{3}\right)$} \\
\cline { 5 - 8 } & & $\mathrm{W}$ & $\mathrm{C}$ & $\mathrm{S}$ & $\mathrm{G}$ & $\mathrm{AE}$ \\
\hline \hline 45 & 86 & 38.6 & & 371 & 696 & 1108 & 0.089 \\
\hline 55 & 83 & 41.6 & \multirow{2}{*}{167} & 304 & 756 & 1106 & 0.045 \\
\hline 6 & 78 & 44.6 & & 257 & 848 & 1153 & 0.031 \\
\hline
\end{tabular}

表 4 コンクリートの圧縮強度および気泡特性

\begin{tabular}{|c|c|c|c|c|}
\hline \multirow{2}{*}{$\begin{array}{l}\mathrm{W} / \mathrm{C} \\
(\%)\end{array}$} & \multirow{2}{*}{$\begin{array}{c}\text { 材齢 } 28 \text { 日における } \\
\text { 圧縮強度（ } \mathrm{MPa} ）\end{array}$} & \multicolumn{2}{|c|}{ 空気量 (\%) } & \multirow{2}{*}{$\begin{array}{c}\text { 気泡間隔係数 } \\
(\mu \mathrm{m})\end{array}$} \\
\hline & & フレッシュ & 硬化後 & \\
\hline 45 & 45.2 & 4.3 & 3.9 & 281 \\
\hline 55 & 39.0 & 3.9 & 3.5 & 318 \\
\hline 65 & 28.6 & 4.1 & 3.6 & 297 \\
\hline
\end{tabular}

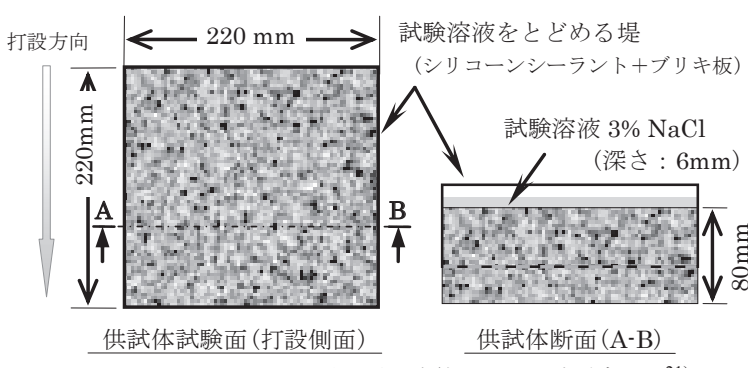

図 20 ASTM C672 法の供試体および試験概要 ${ }^{21)}$

\section{5. 簡易透気試験法の耐凍害性評価への適用（実験シリーズ II） 5.1 実験概要}

（1）使用材料および調合

使用材料として, 普通ポルトランドセメント(密度 : $3.16 \mathrm{~g} / \mathrm{cm}^{3}$ ), 石灰岩砕石 (Gmax : $20 \mathrm{~mm}$, 表乾密度 : $2.69 \mathrm{~g} / \mathrm{cm}^{3}$, 実積率 : $\left.59.2 \%\right)$, 石灰岩砕砂 (表乾密度 : $2.69 \mathrm{~g} / \mathrm{cm}^{3}$, F.M. : 2.59) を使用した。練混ぜ 水は一般水道水とし, 混和剂にはアニオン系界面活性剂を主成分と する $\mathrm{AE}$ 剂を使用した。コンクリートの調合を表 3 に示す。水セメ ント比は $45 \%, 55 \%$ および $65 \%$ の 3 水準とし, 目標スランプ $80 \mathrm{~mm}$, 目標空気量 $4.0 \%$ とした。これらの調合による材齢 28 日の圧縮強度 および気泡特性を表 4 に示す。

（2）供試体作製および養生方法

供試体形状は，スケーリング抵抗性試験 ASTM C672 法 ${ }^{21)}$ に準じ て $220 \times 220 \times 80 \mathrm{~mm}$ の平板形状とし, 水セメント比毎にスケーリン グ試験用 9 体，簡易透気試験用 9 体を作製した。なお，供試体は 440 $\times 220 \times 80 \mathrm{~mm}$ の型枠を用いて作製し，材齢 14 日に乾式切断機を用 いて二分して両試験用に振り分けた。脱型は材齢 1 日で行い，材齢 14 日まで水中養生を行った。試験対象面は, ブリーディングや表面 仕上げに起因する打設上面の不均質性を考慮し，打設側面を用いる 
こととした。スケーリング試験用供試体は, 水中養生後, 材齢 28 日まで $20^{\circ} \mathrm{C} \cdot 60 \%$ R.H.の恒温恒湿室で気中養生を行った。材齢 $21 \sim$ 26 日に, 試験対象面の周囲 4 側面にシリコーンシーラントを用いて ブリキ板を接着し, 図 20 に示すように, 試験溶液を留めるための堤 を作製した。簢易透気試験用供試体については, 水中養生終了後, コンクリート表層部の含水状態の安定を図るため, 材齢 91 日まで実 験室内に静置した。簡易透気試験では, 表面水分率による影響を考 慮し，上記の試験材齢に設定したが，スケーリング試験はコンクリ 一トの特性として, その抵抗性を評価寸るものであることから規格 に準じた養生条件を採用することとした。両試験において養生方法 および養生期間は異なるが, コンクリートの潜在的なスケーリング 抵抗性の評価・比較は可能であると思われる。

（3）スケーリング試験「ASTM C672 法」の概要 ${ }^{21)}$

材齢 28 日に, 試験面から深さ $6 \mathrm{~mm}$ となるよう $\mathrm{NaCl} 3 \%$ 溶液を注 ぎ入れ，ASTM C672 法で規定する凍結融解温度条件 ${ }^{21)}$ を満たすよ う, 人工気象室を用いた自動制御法 ${ }^{24), 25}$ により凍結融解試験を行っ た。凍結融解 5 サイクル毎に試験面から剥離したスケーリング片を ナイロンブラシで採取し, 含有塩分を取り除くためイオン交換水に より洗浄した。その後, $100 \pm 5^{\circ} \mathrm{C}$ 乾燥機で 24 時間乾燥させ, スケ ーリング片の乾燥質量を測定し, その乾燥質量を試験面積で除して 単位面積あたりのスケーリング量 $\left(\mathrm{kg} / \mathrm{m}^{2}\right)$ として算出した。なお， ス ケーリング量の測定は, 凍結融解 60 サイクルまで実施した。

\section{2 実験結果および考察}

図 21 は, ASTM C672 法により得られた凍結融解サイクル数と水 セメント比毎のスケーリング量の関係を示したものである。各水セ メント比におけるスケーリング発生量は，W/C: $45 \%<\mathrm{W} / \mathrm{C}: 55 \%<$ W/C: $65 \%$ という序列関係を示し, 水セメント比によるスケーリング 抵抗性の相違を反映している。水セメント比が大きくなることによ り, 水和反応に寄与しない余剩水やブリーディングの発生が顕著と なり，コンクリート表層には組織的に脆弱な層が形成され ${ }^{23)}$ ，その 結果, スケーリングの発生要因となる水や塩化物といった劣化外力 の侵入・拡散に対する抵抗性が低下し, スケーリング量が増加した ものと考えられる。これは, 表層劣化であるスケーリングの進行が 表層コンクリートの緻密性に大きく依存することを裏付ける。

図 22 は, 簡易透気試験法により得られた簡易透気係数の水セメン 卜比毎の平均值とその変動係数を示したものである。ASTM C672 法 ${ }^{211}$ によるスケーリング量と同様に, 水セメント比による簡易透気 係数は, W/C: $45 \%<\mathrm{W} / \mathrm{C}: 55 \%<\mathrm{W} / \mathrm{C}: 65 \%$ という序列関係を示し, 水 セメント比の異なるコンクリートの透過性の相違を反映している。 また, 各水セメント比における簡易透気係数の変動係数は, 供試体 9 体における算定值として, W/C:45\%では 8.0\%, W/C:55\%では $14.8 \%$, W/C:65\%では $14.3 \%$ となった。

図 23 は, 簡易透気試験法により得られた簡易透気係数と凍結融解 60 サイクル時のスケーリング量との関係を示したものである。簡易 透気係数の大きいコンクリートはスケーリング量も大きくなり, 総 合的に評価した場合, 両者の間には決定係数 0.85 と比較的よい対応 関係が認められる。しかし, 高水セメント比では両者の相関は, 若 干低下寸るように思われる。そこで，W/C:55\%およびW/C:65\%につ いて，それぞれ決定係数を算出した結果，W/C:55\%では 0.65 , W/C:65\%では 0.63 の值が得られた。総合的に評価した場合と比較し

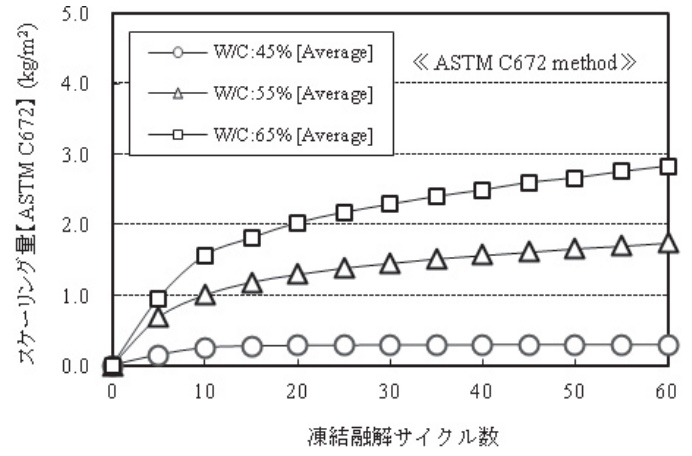

図 21 凍結融解サイクル数とスケーリング量の関係

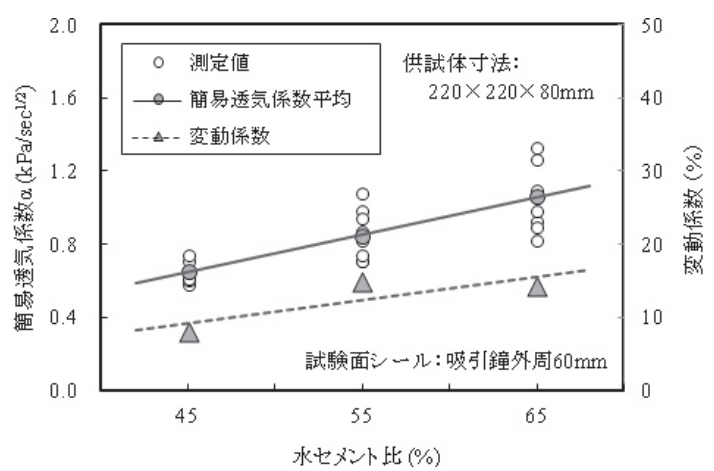

図 22 簡易透気係数 $\alpha$ の平均值と変動係数

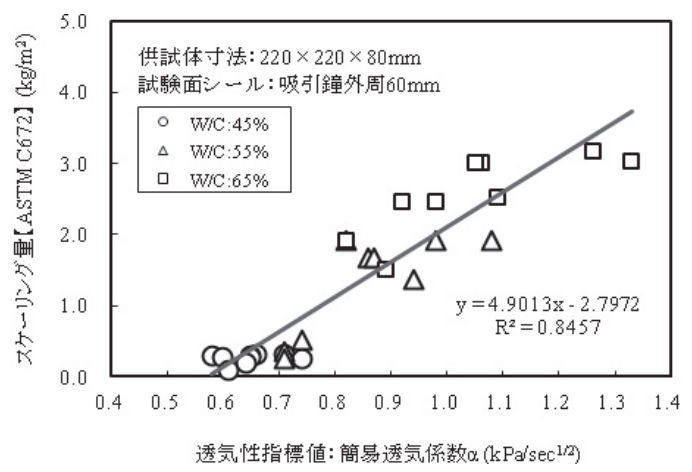

図 23 簡易透気係数とスケーリング量との関係

相関性は低下寸るものの対応傾向にあるものと思われる。このこと から，簡易透気係数はコンクリートのスケーリング抵抗性を反映す るものと考えられ，コンクリートのスケーリング抵抗性評価手法と して，簡易透気試験法を適用できる可能性が示唆された。スケーリ ングはコンクリートの緻密性に起因寸る表層劣化である。この緻密 性を評価する原位置非破壊試験として, 衝撃弹性波 ${ }^{26)}$ や電気抵抗率 27)による間接的評価手法も検討されているが，本研究では，コンク リート表層を対象とした透過性の直接的評価が可能である透気性試 験の適用性について検討し，その妥当性を示すことができたものと 思われる。しかし，現段階においては，実験室レベルの検証にとど まり，実際に簡易透気試験法をスケーリング抵抗性評価手法として 実構造物に適用しようとした場合，更なるデータの蓄積による検討 が必要である。今後，簡易透気試験によるスケーリング抵抗性評価 の適用性を明確にするため, コンクリートの含水状態や気泡特性お よび細孔構造などのミクロ的検討を踏まえ, コンクリート表層の組 織構成と関連付けた透気機構を明らかにしていく必要がある。 


\section{6. まとめ}

本研究では，吸引鐘を用いた簡易透気試験法の基礎特性や適用条 件について検討するとともに，スケーリング抵抗性評価手法として の適用の可能性について実験的に検討を行った。本研究の範囲にお いて，得られた知見を以下にまとめる。

1）簡易透気試験の適用条件として, 吸引鐘外周における試験面シ 一ル幅を $60 \mathrm{~mm}$ に設定することで, 簡易透気係数の変動係数を $15 \%$ 以下とすることが可能であり, 試験面シール幅をさらに拡 張することで試験精度を向上できる可能性が示唆された。

2）簡易透気試験の適用条件として, 部材端部から吸引鐘中心まで の距離を $100 \mathrm{~mm}$ 以上確保することで, 部材端部からの空気流 入による影響を排除できる可能性が示唆された。また，部材端 部から吸引鐘中心までの距離を $150 \mathrm{~mm}$ とすることで, 試験值 の変動係数を $15 \%$ 以下とできる。

3）測定対象部材の厚さが増すことにより, 簡易透気係数は増加傾 向を示寸。これは，部材厚さの違いによって，その厚さや脆弱 度に相違を生じる表層脆弱層を介して, シール外周から空気が 流入することに起因寸るものと考えられる。したがって, 対象 とするコンクリート部材の厚さが $100 \mathrm{~mm}$ 以上であれば，部材 背面からの空気流入による影響は無視できるものと思われる。

4）吸引鐘を小型化することで簡易透気係数は増加するが，コンク リートの透気性の違いを相対的に評価することは可能であり， 吸引鐘の内径を $\phi 100 \mathrm{~mm}$ から $\phi 50 \mathrm{~mm}$ とすることで, 試験時間 を約 70\%短縮することが可能である。

5）簡易透気係数は, RILEM-CEMBUREAU 法 (室内透気試験) と強 度の相関性を持つトレント透気係数と決定係数 0.81 と比較的 よい対応関係を示すことから，簡易型の原位置透気試験として， 有用性が認められるものと思われる。

6）簡易透気試験では，独自設定した透気係数の算出方法を採用し ており計測時間の点で課題を残すが，試験值の変動係数は，卜 レントや今本らの方法と比較して小さな值を示し, 試験精度の 面から，他の方法と同様に有用性が認められるものと思われる。

7）簡易透気係数は, ASTM C672 法により得られるスケーリング量 との間で決定係数 0.85 という相関性を示し, 簡易透気試験法に より得られる透気性指標值を，スケーリング抵抗性を評価する ための指標として，適用できる可能性が示唆された。

\section{参考文献}

1）長㴰重義, 氏家勲：コンクリートの透気性, セメント・コンクリート, No.455, pp.24-31, 1985.1

2) J.W.Figg : Methods of measuring the air and water permeability of concrete, Magazine of Concrete Research, Vol.25, No.85, pp.213-219, 1973.12

3） 月永洋一, 庄谷征美, 杉田修一, 笠井芳夫 : コンクリート表層部の品質 評価に関する基礎的研究，コンクリート工学年次論文報告集，Vol.12， No.1, pp.591-596, 1990.7

4) Y.Tsukinaga, M.Shoya, T.Sugawara : Studies of Methods to Assess the Quality of the Surface Layer of Concrete, ACI SP-128, Vol.1, pp.637-651, 1991.12

5) M.Shoya, Y.Tsukinaga, S.Sugita, T.Hara, K.Domon : On New In-Situ Test Method for Permeability of Concrete, Durability of Building Materials and Components 7, Vol.2, pp.919-928, 1996.5

6) 月永洋一, 庄谷征美, 杉田修一, 石橋学: 簡易試験による表層部コンク リートの透過性評価に関する研究，セメント・コンクリート論文集， No.50, pp.290-295, 1996.12
7） 月永洋一, 庄谷征美, 笠井芳夫, 土門勝司 : 簡易試験による表層部コン クリートの透過性評価に関する研究, 日本建築学会構造系論文集, 第 506 号, pp.7-14, 1998.4

8）庄谷征美，月永洋一，佐々木幹夫，杉田修一：コンクリート表層部に着 目した簡易透水試験法の開発に関する基礎的研究：土木学会論文集, No.627, V-44, pp.133-145, 1999.8

9）権代由範，月永洋一，庄谷征美，阿波稔，菅原隆：チャンバー吸引セルを 用いた簡易透気試験法の有用性に関する基礎的検討, シンポジウム・コン クリート構造物への非破壊検查の展開·論文集, Vol.2, pp.271-276, 2006.8

10）氏家勲：実構造物におけるかぶりコンクリートの吸水性，透水性，透気 性の測定方法, コンクリート工学, Vol.32, No.12, pp.43-47, 1994

11） 今本啓一，下澤和幸，山崎順二，二村誠二 : 実構造物の表層透気性の非 · 微破壊試験方法に関する研究の現状, コンクリート工学, Vol.44, No.2, pp.31-38, 2006.2

12) K.Schönlin and H.Hilsdorf : Evaluation of the effectiveness of curing of concrete structures, ACI SP-100, Concrete Durability. Katharine and Bryant Mather Intern. Confer., Vol.1, pp.207-226, Detroit, ACI, 1987

13) R.Torrent, L.Ebensperger : Studie über Methoden zur Messung und Beurteilung der Kennwerte des Überdeckungsbetons auf der Baustelle - Teil 1, p.119 , Office Féderal des Routes, Suisse, Zürich，Januar，1993

14）福島札規, 浦野英男, 谷川恭雄: 構造体コンクリートの透気性に関寸る 実験的研究, 日本建築学会大会学術講演梗概集 A, pp.911-912, 1993.9

15）今本啓一，山崎順二，下澤和幸，永山勝，二村誠二 : 構造体コンクリー トの表層透気性におけるシングルチャンバー法の適用性の検討, 日本建 築学会構造系論文集, 第 607 号, pp.31-38, 2006.9

16）今本啓一，山崎順二，下澤和幸，永山勝，二村誠二：かぶりコンクリー トの透気性に基づく $\mathrm{RC}$ 構造物の耐久性能検証に向けた基礎的研究，日 本建築学会構造系論文集, 第 74 巻, 第 638 号, pp.593-599, 2009.4

17）庄谷征美, 月永洋一：東北地方のコンクリート構造物の凍害について, コンクリート工学, Vol.42, No.12, pp.3-8, 2004.12

18）菅原隆，木村陽子，権代由範，月永洋一：コンクリート製品の耐久性向 上に関する実験的研究，セメント・コンクリート論文集，No.63， pp.472-477, 2009.2

19）武田三弘，大塚浩司：浸透性吸水防止材によるコンクリートのスケーリ ング抑制効果に関する研究, コンクリート工学論文集, Vol.18, No.1, pp.1-9, 2007.1

20) R.Torrent : A two-chamber vacuum cell for measuring the coefficient of permeability to air of the concrete cover on site, Materials and Structures, Vol.25, No.150, pp.358-365, 1992

21) American Society for Testing and Materials : Standard test method for scaling resistance of concrete surface exposed to de-icing chemicals, Annual Book of ASTM Standard, Vol.04.02, pp.344-346, 1998

22) RILEM TC 116-PCD : Recommendation of TC 116-PCD, Tests for gas permeability of concrete, B. Measurement of the permeability of concrete by the RILEM CEMBUREAU method, Materials \& Structures, Vol.32, No.3, pp.176-179, 1999.4

23）権代由範，月永洋一，庄谷征美，阿波稔：コンクリート部材の断面厚さ の相違が表層部脆弱層の形成に及ぼす影響, セメント・コンクリート論 文集，No.64，pp.391-397，2010.2

24）権代由範，庄谷征美，月永洋一，子田康弘：塩化物環境下におけるス久 ーリング抵抗性の評価試験法に関する基礎的研究, コンクリート工学論 文集，Vol. 20，No.1，pp. 59-70，2009.1

25）月永洋一，庄谷征美，笠井芳夫：凍結防止剤によるコンクリートのスケ ーリング性状とその評価に関する基礎的研究，コンクリート工学論文集， Vol. 8, No.1, pp. 121-133, 1997.1

26）岩野聡史，森濱和正，極檀邦夫，境友昭：鋼球接触時間の測定によるコ ンクリート表層部の品質評価，コンクリート工学年次論文集，Vol.27， No.1，2005

27）榎原彩野，皆川浩，久田真：モルタルの電気抵抗率と塩化物イオン拡散 係数の関係に関する基礎的研究, コンクリート工学年次論文集, Vol. 30, No.1, pp.789-793, 2008

（2011年 8 月10日原稿受理，2012年 4 月18日採用決定） 